\title{
NITROGEN SATURATION IN STREAM ECOSYSTEMS
}

\author{
Stevan R. Earl, ${ }^{1}$ H. Maurice Valett, and Jackson R. Webster \\ Department of Biological Sciences, Virginia Polytechnic Institute and State University, Blacksburg, Virginia 24061-0406
}

\begin{abstract}
The concept of nitrogen (N) saturation has organized the assessment of $\mathrm{N}$ loading in terrestrial ecosystems. Here we extend the concept to lotic ecosystems by coupling Michaelis-Menten kinetics and nutrient spiraling. We propose a series of saturation response types, which may be used to characterize the proximity of streams to $\mathrm{N}$ saturation. We conducted a series of short-term $\mathrm{N}$ releases using a tracer $\left({ }^{15} \mathrm{NO}_{3}-\mathrm{N}\right)$ to measure uptake. Experiments were conducted in streams spanning a gradient of background $\mathrm{N}$ concentration. Uptake increased in four of six streams as $\mathrm{NO}_{3}-\mathrm{N}$ was incrementally elevated, indicating that these streams were not saturated. Uptake generally corresponded to Michaelis-Menten kinetics but deviated from the model in two streams where some other growth-critical factor may have been limiting. Proximity to saturation was correlated to background $\mathrm{N}$ concentration but was better predicted by the ratio of dissolved inorganic N (DIN) to soluble reactive phosphorus (SRP), suggesting phosphorus limitation in several high-N streams. Uptake velocity, a reflection of uptake efficiency, declined nonlinearly with increasing $\mathrm{N}$ amendment in all streams. At the same time, uptake velocity was highest in the low-N streams. Our conceptual model of $\mathrm{N}$ transport, uptake, and uptake efficiency suggests that, while streams may be active sites of $\mathrm{N}$ uptake on the landscape, $\mathrm{N}$ saturation contributes to nonlinear changes in stream $\mathrm{N}$ dynamics that correspond to decreased uptake efficiency.
\end{abstract}

Key words: Michaelis-Menten; nitrate; nitrogen spiraling; nitrogen uptake; saturation; stable isotope; streams.

\section{INTRODUCTION}

Nutrient input to terrestrial landscapes is leading to increased nitrogen $(\mathrm{N})$ loading to aquatic systems. Headwater streams are important links in the transport of $\mathrm{N}$ from enriched terrestrial systems, but in-stream biological processes may also reduce the downstream flux of N (Alexander et al. 2000, Peterson et al. 2001, Bernhardt et al. 2003, Hall 2003). At the same time, the abundance and diversity of stream biota may respond to altered $\mathrm{N}$ supply over short- or long-term time scales. Aber et al. (1989, 1998) proposed the N-saturation hypothesis whereby enhanced inputs of $\mathrm{N}$ outpace forest uptake. They describe a series of $\mathrm{N}$-saturation stages characterized by distinct, nonlinear changes in $\mathrm{N}$ processing leading to increased $\mathrm{N}$ loss at the highest stages of $\mathrm{N}$ saturation. By analogy to forests, saturated low-order streams should pass higher $\mathrm{N}$ loads on to downstream reaches. Here we present an analysis of the relationship between stream water $\mathrm{N}$ concentration and uptake in stream ecosystems spanning a range of chronic $\mathrm{N}$ availability. We used a stable isotope tracer $\left({ }^{15} \mathrm{~N}\right)$ to determine how $\mathrm{N}$ uptake by streams spanning a gradient of dissolved inorganic N (DIN) concentration responds to experimental increases in $\mathrm{N}$ concentration. We

Manuscript received 18 October 2005; revised 17 May 2006; accepted 31 May 2006. Corresponding Editor: S. Findlay.

1 Present address: Global Institute of Sustainability, Arizona State University, Tempe, Arizona 85287-3211 USA. E-mail: Stevan.Earl@asu.edu combined the nutrient spiraling concept (Newbold et al. 1981) to a Michaelis-Menten (M-M) framework to identify and characterize saturation response types analogous to the stages of $\mathrm{N}$ saturation described by Aber et al. (1989, 1998) for forests.

\section{$N$ availability, uptake kinetics, and saturation response types}

The M-M model (Eq. 1) was originally developed to model enzyme kinetics but has proven to be robust in describing nutrient uptake as a function of concentration at a broad range of scales:

$$
U=\frac{U_{\max } C}{C+K_{\mathrm{m}}}
$$

where $U$ is uptake, $C$ is nutrient concentration, $K_{\mathrm{m}}$ is the half-saturation constant, and $U_{\max }$ is maximum uptake. Maximum uptake and the half-saturation constant $\left(K_{\mathrm{m}}\right.$, the concentration at which uptake is one-half of $U_{\max }$ ) vary widely among organisms and in response to environmental conditions. These metrics are indices of organismal or system affinity for a nutrient.

At low concentrations (i.e., $C \ll K_{\mathrm{m}}$ ), uptake approximates a linear relationship with increasing nutrient concentration (Kim et al. 1990). As nutrient concentration increases to near-saturating concentrations, $U$ approaches $U_{\max }$ asymptotically. We contend that these regions of the M-M curve can be abstracted to represent three distinct stages of $\mathrm{N}$ saturation in stream ecosystems. The response of uptake in a stream to short- 
TABle 1. Characteristics of study streams used to assess $\mathrm{N}$ saturation.

\begin{tabular}{|c|c|c|c|c|c|c|c|c|}
\hline Stream & Location & $\begin{array}{l}\mathrm{NO}_{3}-\mathrm{N} \\
(\mu \mathrm{g} / \mathrm{L})\end{array}$ & $\begin{array}{c}\mathrm{NH}_{4}-\mathrm{N} \\
(\mu \mathrm{g} / \mathrm{L})\end{array}$ & $\begin{array}{c}\text { SRP } \\
(\mu \mathrm{g} / \mathrm{L})\end{array}$ & $\mathrm{N}: \mathrm{P}$ & $\begin{array}{l}\text { Width } \\
(\mathrm{cm})\end{array}$ & $\begin{array}{l}\text { Depth } \\
\text { (cm) }\end{array}$ & $\begin{array}{c}\text { Discharge } \\
(\mathrm{L} / \mathrm{s})\end{array}$ \\
\hline Sammy Creek I (spring) & Giles County, Virginia & 5 & 5 & bdl & 3 & 136 & 5 & 7 \\
\hline Sammy Creek II (summer) & Giles County, Virginia & 3 & bdl & bdl & 2 & 71 & 4 & 6 \\
\hline Hugh White Creek & Macon County, North Carolina & 3 & 3 & bdl & 2 & 225 & 2 & 7 \\
\hline Alta Creek & Montgomery County, Virginia & 182 & bdl & 7 & 25 & 249 & 8 & 15 \\
\hline Stonecrop Creek & Giles County, Virginia & 298 & 5 & 20 & 16 & 101 & 3 & 2 \\
\hline Greenbrier Creek & Roanoke County, Virginia & 983 & bdl & 5 & 195 & 190 & 8 & 31 \\
\hline
\end{tabular}

Notes: Nitrate-nitrogen $\left(\mathrm{NO}_{3}-\mathrm{N}\right)$, ammonium-nitrogen $\left(\mathrm{NH}_{4}-\mathrm{N}\right)$, and soluble reactive phosphorus (SRP) are reach-average concentrations prior to all releases. $\mathrm{N}: \mathrm{P}$ represents atomic ratios derived from the combined concentrations of $\mathrm{NO}_{3}-\mathrm{N}$ and $\mathrm{NH}_{4}-\mathrm{N}$ to SRP. The lowest detectable limit $(3 \mu \mathrm{g} / \mathrm{L})$ was used to calculate N:P when measured concentrations were below detectable limits (bdl). Width, depth, and discharge reflect reach mean measurements.

term additions of $\mathrm{N}$ should follow one of these saturation response types (SRTs) that correspond to a stream's proximity to uptake saturation. Thus, SRTs are delineated by the relationship between uptake and concentration, including: (1) Type I, exhibiting a constant, linear increase (slope $>0$ ) in uptake, indicating that a stream is well below saturation, (2) Type II, uptake increasing to an asymptotic plateau (curvilinear, slope $>0$ but declining), indicating that a stream is approaching saturation, and (3) Type III, no increase in uptake in response to nutrient amendment, characterizing a nutrient-saturated stream.

\section{Linking uptake kinetics, $N$ saturation, and nutrient spiraling}

Solutes in streams are simultaneously affected by processes that assimilate or transform nutrients and by forces that cause downstream transport of dissolved and suspended material. The nutrient spiraling concept (Webster and Patten 1979) incorporates both downstream transport and cycling of nutrients within streams and provides a conceptual and technical framework for stream biogeochemistry (Newbold et al. 1981). Three commonly measured indices are used to describe spiraling in streams. (1) Uptake length $\left(S_{\mathrm{w}}\right)$ is the mean distance traveled as a dissolved inorganic solute before immobilization and removal from the water column. (2) Uptake velocity $\left(v_{\mathrm{f}}\right)$ represents the theoretical speed at which a nutrient moves toward a sink (i.e., stream bottom) and standardizes for stream depth and velocity (Stream Solute Workshop 1990):

$$
v_{\mathrm{f}}=\frac{d}{S_{\mathrm{w}}} u
$$

where $u$ is stream-water velocity and $d$ is stream depth. (3) Areal specific uptake $(U)$ quantifies the mass of nutrient immobilized per area of streambed per unit time (Stream Solute Workshop 1990):

$$
U=v_{\mathrm{f}} C
$$

where $C$ is stream water nutrient concentration. Examination of Eqs. 2 and 3 shows that, in addition to standardizing for stream morphometry and hydraulics, $v_{\mathrm{f}}$ reflects nutrient uptake relative to concentration (i.e., $U / C$ ) and thus serves as a descriptor of nutrient uptake efficiency (Davis and Minshall 1999).

Because the spiraling metrics $\left(S_{\mathrm{w}}, v_{\mathrm{f}}\right.$, and $\left.U\right)$ are mathematically related, applying the M-M model to $U$ dictates how $S_{\mathrm{w}}$ and $v_{\mathrm{f}}$ should respond to increasing nutrient concentration. The uptake velocity $\left(v_{\mathrm{f}}\right)$ is described by a nonlinear decrease with increasing nutrient concentration:

$$
v_{\mathrm{f}}=\frac{U_{\max }}{K_{\mathrm{m}}+C} .
$$

At the same time, $S_{\mathrm{w}}$ increases linearly with increasing nutrient concentration:

$$
S_{\mathrm{w}}=u d\left(\frac{C+K_{\mathrm{m}}}{U_{\max }}\right) .
$$

Both $K_{\mathrm{m}}$ and $U_{\max }$ can be derived from empirical relationships between nutrient concentration and any of the spiraling metrics. We used stable $\mathrm{N}$-isotope (i.e., $\left.{ }^{15} \mathrm{~N}\right)$ solute release experiments to assess ecosystem uptake response to experimental $\mathrm{N}$ additions in streams spanning a gradient of $\mathrm{N}$ concentration.

\section{Methods \\ Study sites}

We examined $\mathrm{N}$ uptake across five first- or secondorder headwater streams in the southern Appalachian Mountains of southwestern Virginia and western North Carolina, USA (Table 1) selected to span a gradient of background dissolved inorganic nitrogen (DIN) concentration. The concentration of DIN in our study streams is characteristic of the range of DIN concentration reported in other streams throughout the region (McTammany 2004, Hagen et al. 2006; Webster and Valett, unpublished data). Streams were bordered by forested riparian zones, but land use within associated catchments was variable. Two streams (Sammy Creek and Hugh White Creek) were located within forested catchments that have been relatively undisturbed by human activities since the 1920s. Vegetation included mixed deciduous forests with thick streamside canopies of rhododendron (Rhododendron maxium L.). Catchments of the other streams (Alta Creek [see Plate 1], Greenbrier Creek, and Stonecrop Creek) included a 
TABLE 2. Enrichment levels and spiraling metrics from individual releases.

\begin{tabular}{|c|c|c|c|c|c|}
\hline Stream and date & $\begin{array}{c}\text { Discharge } \\
(\mathrm{L} / \mathrm{s})\end{array}$ & $\begin{array}{l}\mathrm{NO}_{3}-\mathrm{N} \\
(\mu \mathrm{g} / \mathrm{L})\end{array}$ & $\begin{array}{l}S_{\mathrm{w}} \\
(\mathrm{m})\end{array}$ & $\begin{array}{c}v_{\mathrm{f}} \\
(\mathrm{mm} / \mathrm{min})\end{array}$ & $\frac{U}{\left(\mu \mathrm{g} \mathrm{N} \cdot \mathrm{m}^{-2} \cdot \min ^{-1}\right)}$ \\
\hline \multicolumn{6}{|l|}{ Sammy Creek I } \\
\hline 29 April 2003 & 9.0 & 5 & $128 \pm 21$ & 1.57 & 7.8 \\
\hline 1 May 2003 & 6.8 & 47 & $181 \pm 22$ & 0.83 & 39.0 \\
\hline \multicolumn{6}{|l|}{ Sammy Creek II } \\
\hline 15 July 2003 & 6.1 & 3 & $42 \pm 3$ & 2.09 & 5.1 \\
\hline 16 July 2003 & 6.1 & 140 & $88 \pm 9$ & 0.74 & 103.7 \\
\hline \multicolumn{6}{|l|}{ Hugh White Creek } \\
\hline 8 October 2003 & 6.8 & 3 & $23 \pm 2$ & 2.80 & 8.8 \\
\hline 9 October 2003 & 7.0 & 39 & $175 \pm 2$ & 0.37 & 14.6 \\
\hline 10 October 2003 & 7.7 & 260 & $508 \pm 14$ & 0.14 & 36.8 \\
\hline 11 October 2003 & 8.2 & 537 & $816 \pm 15$ & 0.09 & 48.1 \\
\hline \multicolumn{6}{|l|}{ Alta Creek } \\
\hline 25 August 2003 & 15.5 & 181 & $587 \pm 81$ & 0.46 & 84.0 \\
\hline 26 August 2003 & 15.3 & 223 & $1157 \pm 135$ & 0.22 & 49.8 \\
\hline 27 August 2003 & 15.6 & 360 & $3128 \pm 543$ & 0.08 & 30.2 \\
\hline 28 August 2003 & 13.5 & 577 & $5464 \pm 715$ & 0.05 & 26.8 \\
\hline \multicolumn{6}{|l|}{ Stonecrop Creek } \\
\hline 10 September 2003 & 2.2 & 287 & $632 \pm 24$ & 0.09 & 26.5 \\
\hline 11 September 2003 & 2.0 & 361 & $684 \pm 84$ & 0.09 & 30.7 \\
\hline 12 September 2003 & 1.9 & 575 & $1002 \pm 38$ & 0.06 & 35.7 \\
\hline 13 September 2003 & 2.1 & 850 & $1263 \pm 131$ & 0.05 & 41.8 \\
\hline \multicolumn{6}{|l|}{ Greenbrier Creek } \\
\hline 14 August 2003 & 32.0 & 981 & $3652 \pm 1037$ & 0.23 & 222.4 \\
\hline 14 August 2003 & 32.0 & 1081 & NS & & \\
\hline 15 August 2003 & 29.0 & 1240 & $5519 \pm 1264$ & 0.14 & 173.1 \\
\hline 15 August 2003 & 29.0 & 1568 & $7194 \pm 1136$ & 0.11 & 167.9 \\
\hline
\end{tabular}

Notes: Values for uptake length $\left(S_{\mathrm{w}}\right)$ are means $\pm \mathrm{SE}$. $\mathrm{NO}_{3}-\mathrm{N}$ represents the geometric mean of the $\mathrm{NO}_{3}-\mathrm{N}$ concentration $(\mu \mathrm{g} / \mathrm{L})$ in the study reach during plateau sampling. NS indicates a nonsignificant $(P \geq 0.05)$ regression.

mixture of forest, small farms, and residential areas. The substratum of Sammy Creek and Alta Creek was dominated by small cobbles and boulders, whereas a mix of sand, gravel, and silt dominated the substratum at each of the other three streams (Earl 2004). Study streams were characterized by soft water, with the exception of Stonecrop Creek, which drained a predominately limestone catchment. We selected a single study reach $(50-388 \mathrm{~m})$ in each stream, with length depending on accessibility, stream water travel time, and distance appropriate to accurately measure $\mathrm{N}$ uptake.

\section{Solute addition experiments}

A series (2-4) of short-term (3-5 h) nutrient releases were used to manipulate stream water nitrate- $\mathrm{N}_{\left(\mathrm{NO}_{3}-\right.}$ $\mathrm{N})$ concentration. At the same time, ${ }^{15} \mathrm{NO}_{3}-\mathrm{N}$ was added as a tracer to measure uptake response to increasing $\mathrm{NO}_{3}-\mathrm{N}$ availability. At each stream, a single release was conducted each day over several consecutive days except at Greenbrier Creek, where two releases were conducted consecutively over two days (Table 2). Releases were conducted during periods without storms to address generally similar climatic and hydraulic conditions. Prior to release, background samples were collected from four to seven points along the study reach and analyzed for $\mathrm{NO}_{3}-\mathrm{N}$, chloride $\left(\mathrm{Cl}^{-}\right)$, and ${ }^{15} \mathrm{NO}_{3}-\mathrm{N}$. A subset of the background samples was analyzed for ambient concentrations of ammonium- $\mathrm{N}\left(\mathrm{NH}_{4}-\mathrm{N}\right)$ and soluble reactive phosphorus (SRP).

For the first release, a solution of $\mathrm{K}^{15} \mathrm{NO}_{3}$ (98 atom percentage; Cambridge Isotope Laboratories, Andover, Massachusetts, USA) and $\mathrm{NaCl}\left(\mathrm{Cl}^{-}\right.$to act as a conservative tracer, Bencala et al. 1990) was released at a constant rate designed to increase stream water $\delta^{15} \mathrm{NO}_{3}-\mathrm{N}$ by $500 \%$. Tracer ${ }^{15} \mathrm{NO}_{3}-\mathrm{N}$ additions elevated stream water $\mathrm{NO}_{3}-\mathrm{N}$ concentration $11 \%$ above ambient at Hugh White Creek, and 9\% and 3\% at Sammy Creek II (summer) and I (spring), respectively, and $<0.6 \%$ at all other sites.

Three replicate water samples were collected from four to seven points (depending upon study reach length) downstream of the release site under well-mixed conditions (i.e., as indicated by steady-state conductivity in channel water). Samples for the analysis of ${ }^{15} \mathrm{NO}_{3}-\mathrm{N}$ were collected in acid-washed 4-L bottles, chilled until filtered (glass-fiber filters, Whatman GF/F, pore size $=$ $1.0 \mu \mathrm{m}$; Florham Park, New Jersey, USA), and refrigerated $\left(\sim 4^{\circ} \mathrm{C}\right)$ for less than one week until processed. Additional samples $(n=3$ per transect) were collected for analysis of $\mathrm{NO}_{3}-\mathrm{N}$ and $\mathrm{Cl}^{-}$, filtered (glassfiber filters, Gelman A/E, pore size $=1.0 \mu \mathrm{m}$; Ann Arbor, Michigan, USA), and frozen that day. 
Identical methods were employed for subsequent ${ }^{15} \mathrm{~N}$ releases at each stream; however, varying quantities (Table 2) of $\mathrm{NaNO}_{3}$ were added to the release solution to increase stream water $\mathrm{NO}_{3}-\mathrm{N}$ concentration. Target $\delta^{15} \mathrm{NO}_{3}$ - $\mathrm{N}$ (i.e., $500 \%$ ) was maintained by adjusting the amount of $\mathrm{K}^{15} \mathrm{NO}_{3}$ in the release solution as necessary.

Stream water conductivity was continuously monitored at the downstream end of the study reach, and velocity was determined from the corresponding conservative tracer curve (Bencala and Walters 1983). Discharge $(Q)$ at each transect was determined by dilution gauging using the conservative tracer $\left(\mathrm{Cl}^{-}\right)$ and assumed to be constant throughout sampling. Widths and depths of the wetted channel were measured at $5-10 \mathrm{~m}$ intervals along the study reach prior to or following the series of releases.

\section{Laboratory methods}

Anions $\left(\mathrm{NO}_{3}-\mathrm{N}\right.$ and $\left.\mathrm{Cl}^{-}\right)$were analyzed on a Dionex DX500 Ion Chromatograph (Dionex, Sunnyvale, California, USA). Due to low $\mathrm{NO}_{3}-\mathrm{N}$ concentrations $(<10$ $\mu \mathrm{g} / \mathrm{L}$ ), samples collected at Sammy Creek and Hugh White Creek were analyzed colorimetrically following reduction by Cd (Wood et al. 1967, APHA 1998) on a Technicon Autoanalyzer (Technicon, Emeryville, California, USA). Samples were analyzed for $\mathrm{NH}_{4}-\mathrm{N}$ using a modified phenol-hypochlorite method (Solorzano 1969, USEPA 1997a) and SRP using the molybdateantimony method (Murphy and Riley 1962, USEPA 1997b). DIN was calculated as the sum of $\mathrm{NO}_{3}-\mathrm{N}$ and $\mathrm{NH}_{4}-\mathrm{N}$. Atomic N:P ratios were determined using DIN and SRP concentrations.

${ }^{15} \mathrm{NO}_{3}-\mathrm{N}$ was measured by headspace diffusion according to Sigman et al. (1997). Ammonium was removed by boiling samples to a final volume of $\sim 100$ $\mathrm{mL}$ under basic conditions by adding $\mathrm{MgO}$. Nitrate- $\mathrm{N}$ was converted to ammonia $\left(\mathrm{NH}_{3}\right)$ by adding Devarda's Alloy. A precombusted, acidified ( $\left.25 \mu \mathrm{L}, 2.5 \mathrm{M} \mathrm{KHSO}_{4}\right)$ glass-fiber filter (Whatman GF/D) encased by Teflon tape was added to the sample immediately after adding the Devarda's alloy. Sealed samples were incubated at $60^{\circ} \mathrm{C}$ for $48 \mathrm{~h}$ and then shaken gently for $10 \mathrm{~d}$ during which time $\mathrm{NH}_{3}$ was captured by the acidified filter. The filters were then removed from the Teflon sandwich, dried, tinned, and shipped to the University of California, Davis Stable Isotope Facility (Davis, California) for analysis of ${ }^{15} \mathrm{~N}$ on a Europa Integra mass spectrometer (Sercon, Cheshire, UK).

In the two streams with background $\mathrm{NO}_{3}-\mathrm{N}$ concentrations $<80 \mu \mathrm{g} / \mathrm{L}$ (Sammy Creek and Hugh White Creek; Table 1), background and plateau samples were spiked with a known amount of $\mathrm{NO}_{3}-\mathrm{N}$ to ensure a minimum mass $(\geq 80 \mu \mathrm{g})$ of $\mathrm{N}$ required to measure ${ }^{15} \mathrm{NO}_{3}-\mathrm{N}$ in a reasonable sample volume (i.e., $\leq 1 \mathrm{~L}$ ). Thus, the target $\delta^{15} \mathrm{NO}_{3}-\mathrm{N}$ of the field release was elevated such that the sample $\delta^{15} \mathrm{NO}_{3}-\mathrm{N}$ would reflect an enrichment of $500 \%$ after spike addition.

\section{Data analysis}

Uptake length $\left(S_{\mathrm{w}}\right)$ was calculated by fitting an exponential decay model (SigmaPlot, SPSS, Chicago, Illinois, USA) to the background- and dilution-corrected flux of ${ }^{15} \mathrm{NO}_{3}-\mathrm{N}$ (determined following Mulholland et al. 2000) vs. distance downstream. The decay coefficient represents the longitudinal loss rate $\left(k_{\mathrm{L}}\right)$, and its negative inverse is the uptake length (Newbold et al. 1981). The standard error (SE) of $S_{\mathrm{w}}$ was determined as the standard error of the uptake coefficient using a modified exponential decay model:

$$
{ }^{15} \mathrm{NO}_{3}-\mathrm{N} \text { flux }=a e^{\left(x / S_{\mathrm{w}}\right)} .
$$

where $a$ is equal to the ${ }^{15} \mathrm{NO}_{3}$ - $\mathrm{N}$ flux at the upper-most transect, and $x$ is distance downstream. Uptake velocity $\left(v_{\mathrm{f}}\right)$ and uptake $(U)$ were calculated according to Stream Solute Workshop (1990) following Eqs. 2 and 3, respectively. In Eq. 3, $C$ was the geometric mean of plateau $\mathrm{NO}_{3}-\mathrm{N}$ from all sampling points. Linear and nonlinear regression were used to relate spiraling metrics $\left(S_{\mathrm{w}}, v_{\mathrm{f}}, U\right)$ to $\mathrm{NO}_{3}-\mathrm{N}$ amendment concentration. Linear regression, performed with SigmaStat (SPSS, Chicago, Illinois, USA), was used to assess the relationship between $S_{\mathrm{w}}$ and $\mathrm{NO}_{3}-\mathrm{N}$ amendment concentration. The nonlinear regression function in SigmaPlot was used to relate amendment $\mathrm{NO}_{3}-\mathrm{N}$ concentration to $v_{\mathrm{f}}$ and $U$ according to Eqs. 4 and 1, respectively. In addition, whole-stream estimates of $K_{\mathrm{m}}$ and $U_{\max }$ were calculated from each of these relationships. The slopes of the relationships between $S_{\mathrm{w}}$ and $\mathrm{NO}_{3}-\mathrm{N}$ amendment for each stream were compared by ANCOVA using the PROC REG procedure in SAS. Significance level $(\alpha)$ was set to 0.05 for all statistical tests.

Saturation response type (SRT) for each stream was determined by the best-fit regression between $U$ and $\mathrm{NO}_{3}-\mathrm{N}$ amendment concentration. The relationship at each stream was assessed with a linear and nonlinear (Eq. 1) model. A significant linear model indicated an SRT I designation whereas a significant nonlinear model with positive coefficients indicated an SRT II designation. In the event that both models were statistically significant, model $r^{2}$ was used to identify the appropriate model. Streams were designated SRT III if there was no statistically significant increase in uptake. Model significance and $r^{2}$ were used to identify the best-fit model in lieu of traditional goodness-of-fit tests, due to the small sample size.

\section{RESULTS}

All five streams were relatively small, with mean depth ranging between $2 \mathrm{~cm}$ and $8 \mathrm{~cm}$, and mean width ranging between $71 \mathrm{~cm}$ and $249 \mathrm{~cm}$ (Table 1). The study streams varied in discharge from $2 \mathrm{~L} / \mathrm{s}$ to $31 \mathrm{~L} / \mathrm{s}$ at the time of the release, and mean concentrations of $\mathrm{NH}_{4}-\mathrm{N}$ were consistently low $(\leq 5 \mu \mathrm{g} / \mathrm{L})$, while background $\mathrm{NO}_{3}-\mathrm{N}$ varied from $3 \mu \mathrm{g} / \mathrm{L}$ to $982 \mu \mathrm{g} / \mathrm{L}$ (Table 1 ). The concentration of SRP was $\leq 7 \mu \mathrm{g} / \mathrm{L}$, with the exception 


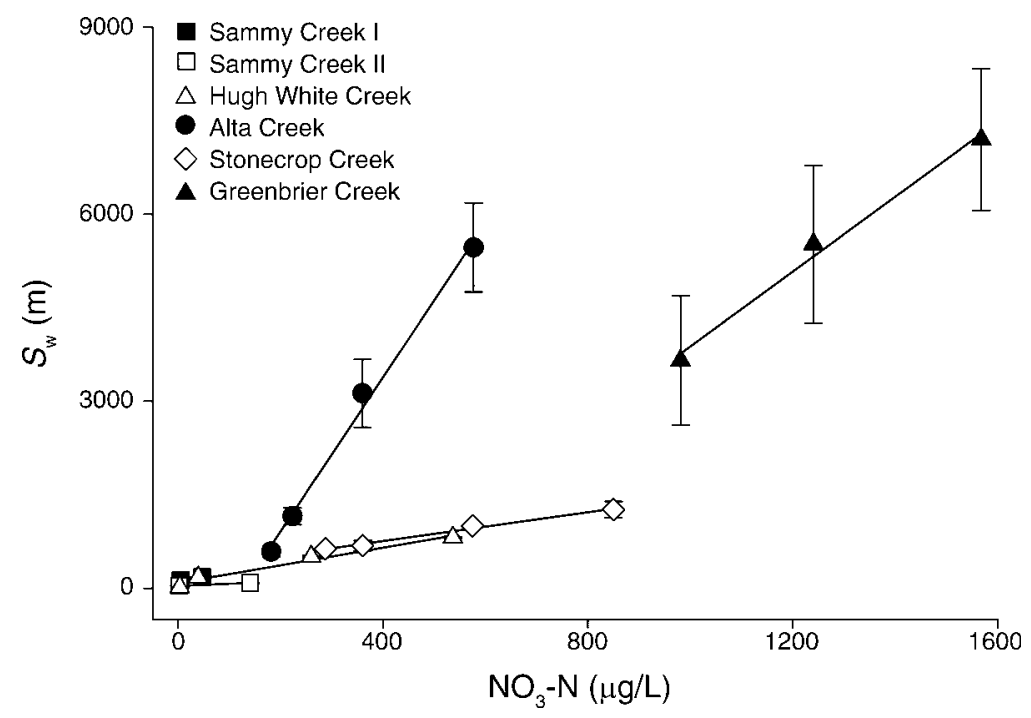

FIG. 1. Response of uptake length $\left(S_{\mathrm{w}}\right.$, mean $\left.\pm \mathrm{SE}\right)$, the distance traveled as a dissolved inorganic solute before immobilization and removal from the water column, to $\mathrm{N}$ amendments for all releases at Sammy Creek I, Sammy Creek II, Hugh White Creek, Alta Creek, Stonecrop Creek, and Greenbrier Creek. The first point for each stream corresponds to $S_{\mathrm{w}}$ measured at the ambient stream water $\mathrm{NO}_{3}-\mathrm{N}$ concentration; subsequent points correspond to $S_{\mathrm{w}}$ measured in association with $\mathrm{NO}_{3}-\mathrm{N}$ amendments. Nitrogen amendment concentration is presented as the geometric mean of plateau $\mathrm{NO}_{3}-\mathrm{N}$ concentration $(\mu \mathrm{g} / \mathrm{L})$ in the study reach. Linear regression lines are presented for all streams except Sammy Creek I and II, for which only two releases were conducted during each experiment.

of Stonecrop Creek $(20 \mu \mathrm{g} / \mathrm{L})$. Atomic N:P varied from 2 to 195 among sites.

\section{Response to $N$ amendments}

For all streams, uptake length $\left(S_{\mathrm{w}}\right)$ increased with increasing $\mathrm{NO}_{3}-\mathrm{N}$ amendment (Fig. 1). Significant, positive, linear relationships between $S_{\mathrm{w}}$ and $\mathrm{NO}_{3}-\mathrm{N}$ concentration occurred at Alta Creek, Stonecrop Creek, and Hugh White Creek $\left(r^{2} \geq 0.975, P \leq 0.013\right)$. While $S_{\mathrm{w}}$ increased with $\mathrm{NO}_{3}-\mathrm{N}$ amendment concentration during experiments at Sammy Creek (I and II), only two additions were completed at these sites, thus limiting curve assessment. Uptake length also increased with increasing $\mathrm{NO}_{3}-\mathrm{N}$ amendment concentration at Greenbrier Creek; however, the relationship was not significant $\left(r^{2}=0.990, P=0.063\right)$, reflecting low statistical power (i.e., $n=3$ releases). The relationship between ${ }^{15} \mathrm{NO}_{3}-\mathrm{N}$ flux and distance downstream during the first amended release at Greenbrier Creek (14 August 2003, $1081 \mu \mathrm{g} \mathrm{NO}_{3}-\mathrm{N} / \mathrm{L}$; Table 2$)$ was not significant $(P=$ $0.141)$ resulting from unusually high variability of $\delta^{15} \mathrm{NO}_{3}-\mathrm{N}$ values. This was the only occurrence of a nonsignificant estimate of $S_{\mathrm{w}}$, and the value was not plotted or included in analyses. In general, there was considerable uncertainty surrounding estimates of $S_{\mathrm{w}}$ at Greenbrier Creek (Table 2, Fig. 1).

Uptake velocity $\left(v_{\mathrm{f}}\right)$ declined in a curvilinear manner with increasing $\mathrm{NO}_{3}-\mathrm{N}$ amendment concentration at most sites (Fig. 2). Significant $(P \leq 0.029)$ relationships between $v_{\mathrm{f}}$ and $\mathrm{NO}_{3}-\mathrm{N}$ amendment concentration were evident at Alta Creek, Stonecrop Creek, and Hugh White Creek. Similarly, $v_{\mathrm{f}}$ declined in a curvilinear manner at Greenbrier Creek, but the regression was not significant ( $P=0.065$, Fig. 2). In addition, $v_{\mathrm{f}}$ decreased with $\mathrm{NO}_{3}-\mathrm{N}$ amendment concentration during both spring and summer collections at Sammy Creek.

Relationships between uptake $(U)$ and $\mathrm{NO}_{3}-\mathrm{N}$ amendment concentration differed among sites (Fig. 3). At Sammy Creek, $U$ increased with increasing $\mathrm{NO}_{3}$ $\mathrm{N}$ amendment concentration during both experiments. Despite an apparent curvilinear fit $\left(r^{2}=0.940\right.$, Eq. 1), the relationship between $U$ and $\mathrm{NO}_{3}-\mathrm{N}$ amendment concentration at Hugh White Creek was best described by a linear model $\left(r^{2}=0.947\right)$. Uptake and $\mathrm{NO}_{3}-\mathrm{N}$ amendment concentration at Stonecrop Creek was better fit by an asymptotic model $\left(r^{2}=0.989\right)$ than a linear model $\left(r^{2}=0.976\right)$. Uptake generally declined with $\mathrm{NO}_{3}-\mathrm{N}$ amendment concentration at Greenbrier Creek and Alta Creek, but linear regression indicated that the slope of the relationship between $U$ and $\mathrm{NO}_{3}-\mathrm{N}$ amendment concentration was not significant for either stream (Fig. 3).

For a given stream, estimates of $K_{\mathrm{m}}$ and $U_{\max }$ calculated from each of the spiraling metrics were generally similar (coefficient of variation [mean/sD] $\leq$ $52 \%$ for all but Hugh White Creek; Table 3). Differences among values of $K_{\mathrm{m}}$ or $U_{\max }$ calculated from each of the three spiraling metrics within a given stream likely reflect variability in variables associated with conversion (i.e., $u, d$, and $C$ ). Over four of the six experiments, mean $K_{\mathrm{m}}$ varied from 59 to $303 \mu \mathrm{g} / \mathrm{L}$ and $U_{\max }$ from 19 to $158 \mu \mathrm{g}$ $\mathrm{N} \cdot \mathrm{m}^{-2} \cdot \mathrm{min}^{-1}$ (Table 3 ). All calculated values for $K_{\mathrm{m}}$ were negative, and calculated $U_{\max }$ values were far 

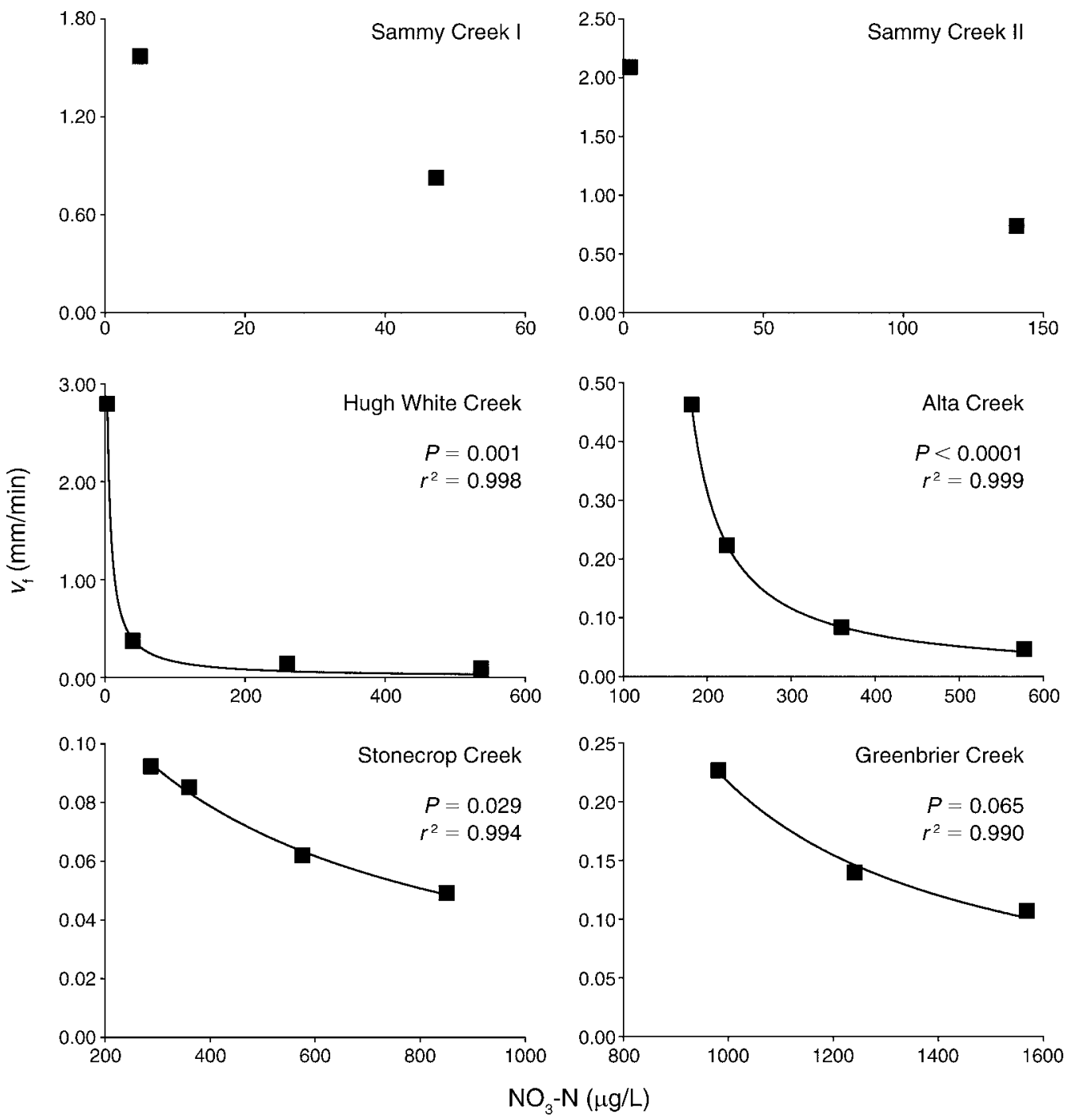

FIG. 2. Uptake velocity $\left(v_{\mathrm{f}}\right)$ responses to $\mathrm{N}$ amendments. The first point in each panel corresponds to $v_{\mathrm{f}}$ measured at the ambient stream water $\mathrm{NO}_{3}-\mathrm{N}$ concentration; subsequent points correspond to $v_{\mathrm{f}}$ measured in association with $\mathrm{NO}_{3}-\mathrm{N}^{2}$ amendments. Nitrogen amendment concentration is presented as the geometric mean of plateau $\mathrm{NO}_{3}-\mathrm{N}$ concentration $(\mu \mathrm{g} / \mathrm{L})$ in the study reach. Results of nonlinear regression following Eq. 4 are presented for those streams for which more than two releases were conducted.

below observed uptake $(U)$ at both Greenbrier Creek and Alta Creek (Table 3).

Negative estimates of M-M parameters (i.e., $K_{\mathrm{m}}$ and $\left.U_{\text {max }}\right)$ at Greenbrier Creek and Alta Creek reflect basic differences in spiraling responses to $\mathrm{N}$ amendment compared to the other study streams. The negative intercepts associated with the regression relating $S_{\mathrm{w}}$ and $\mathrm{NO}_{3}-\mathrm{N}$ amendment at these two streams corresponded to the negative $K_{\mathrm{m}}$ values (Eq. 5, Table 3). Slopes of $S_{\mathrm{w}}$ vs. $\mathrm{NO}_{3}-\mathrm{N}$ amendment concentration at both Greenbrier Creek and Alta Creek were significantly greater (ANCOVA, $P \leq 0.002, \alpha=0.008$, after Bonferroni correction) than slopes at both Stonecrop Creek and Hugh White Creek. Due to the limited number of data points, experiments at Sammy Creek were not included in the statistical comparison, but slopes from these experiments were similar to those at Stonecrop Creek and Hugh White Creek (Fig. 1).

\section{Patterns across streams}

Spiraling metrics across study streams under ambient $\mathrm{N}$ conditions (i.e., ${ }^{15} \mathrm{NO}_{3}-\mathrm{N}$ tracer-derived) varied considerably depending on background stream-water $\mathrm{N}$ concentration. Ambient $S_{\mathrm{w}}$ increased from $23 \mathrm{~m}$ to $3652 \mathrm{~m}$ with increasing $\mathrm{N}$ concentration and a linear model explained most of the variability $\left(r^{2}=0.979, P<\right.$ 0.001). Ambient $v_{\mathrm{f}}$ varied from $0.09 \mathrm{~mm} / \mathrm{min}$ to 2.80 $\mathrm{mm} / \mathrm{min}$ and, as within streams, decreased nonlinearly (Eq. 2) with increasing background stream water $\mathrm{NO}_{3}-\mathrm{N}$ concentration $\left(r^{2}=0.887, P=0.005\right)$. Ambient $U$ varied from $5.1 \mu \mathrm{g} \cdot \mathrm{m}^{-2} \cdot \mathrm{min}^{-1}$ to $222.4 \mu \mathrm{g} \cdot \mathrm{m}^{-2} \cdot \mathrm{min}^{-1}$ and the relationship between $U$ and the background stream 

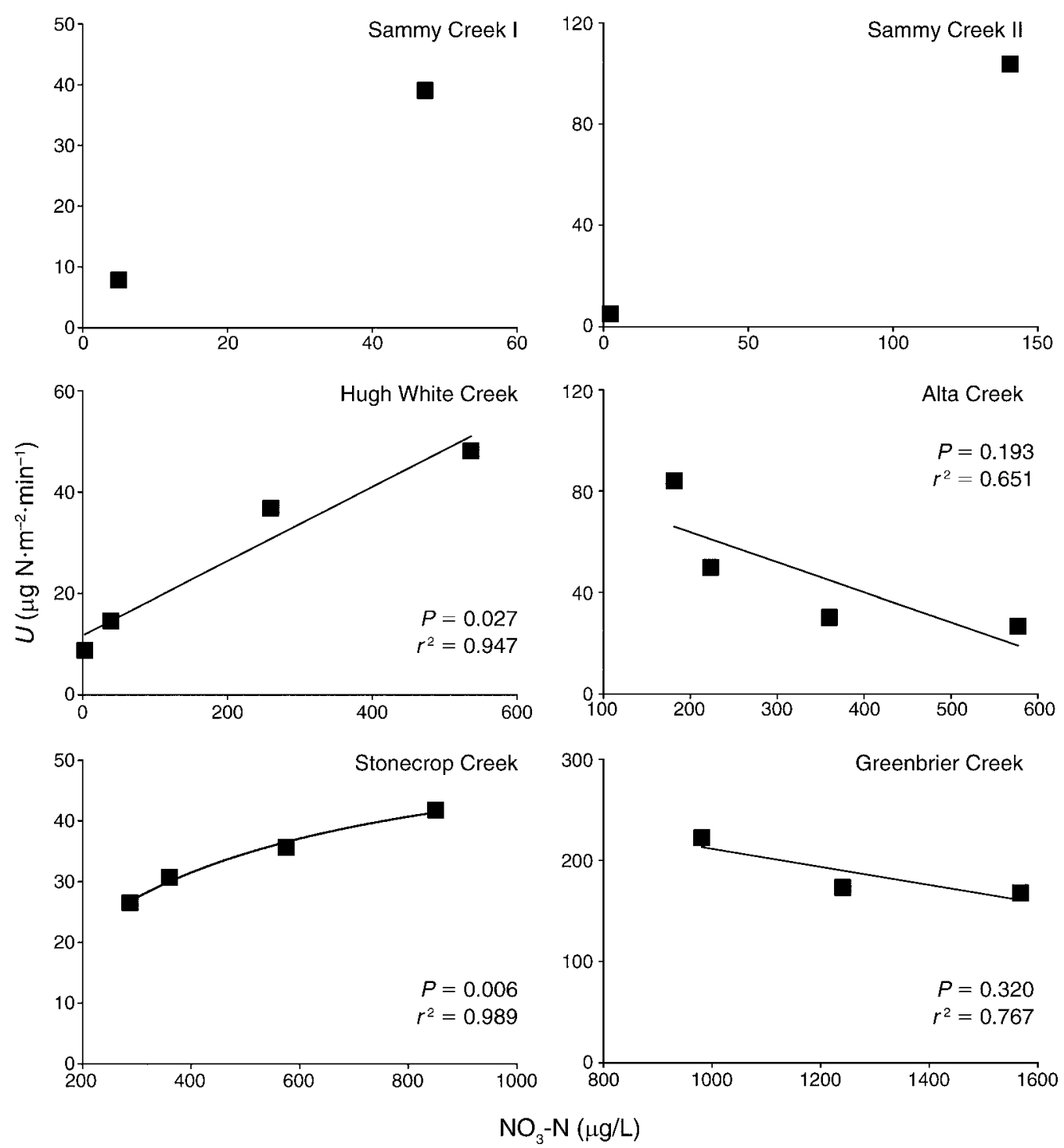

FIG. 3. Uptake $(U)$ response to $\mathrm{N}$ amendments. Symbols and analysis details are as in Fig. 2. Regression models are either linear or curvilinear (following Eq. 1), depending on best fit as indicated by model $r^{2}$.

water $\mathrm{NO}_{3}-\mathrm{N}$ concentration was well described by both linear $\left(r^{2}=0.767, P=0.022\right)$ and nonlinear (Eq. $1 ; r^{2}=$ $0.902, P=0.004)$ models. Although regression statistics from the nonlinear model indicated a good fit to the data, the model resulted in nonsensical coefficients $\left(K_{\mathrm{m}}\right.$ $\left.>1.9 \times 10^{6} \mu \mathrm{g} / \mathrm{L}, U_{\max }>4 \times 10^{5} \mu \mathrm{g} \cdot \mathrm{m}^{-2} \cdot \mathrm{min}^{-1}\right)$, and a visual inspection indicated that the relationship was better fit by a linear model.

TABLE 3. Half-saturation constant $\left(K_{\mathrm{m}}\right)$ and maximum uptake $\left(U_{\max }\right)$ values calculated from regressions among $\mathrm{NO}_{3}-\mathrm{N}$ amendments, $S_{\mathrm{w}}, v_{\mathrm{f}}$, and $U$, at five study streams from April through October 2004.

\begin{tabular}{|c|c|c|c|c|c|c|c|c|c|c|}
\hline \multirow[b]{2}{*}{ Stream } & \multicolumn{5}{|c|}{$K_{\mathrm{m}}(\mu \mathrm{g} / \mathrm{L})$} & \multicolumn{5}{|c|}{$U_{\max }\left(\mu \mathrm{g} \mathrm{N} \cdot \mathrm{m}^{-2} \cdot \min ^{-1}\right)$} \\
\hline & $S_{\mathrm{w}}$ & $v_{\mathrm{f}}$ & $U$ & Mean & $\mathrm{CV}$ & $S_{\mathrm{w}}$ & $v_{\mathrm{f}}$ & $U$ & Mean & $\mathrm{CV}$ \\
\hline Sammy Creek I $\dagger$ & 96 & 42 & 42 & 60 & 52 & 138 & 74 & 74 & 95 & 39 \\
\hline Sammy Creek II $\dagger$ & 118 & 73 & 73 & 88 & 30 & 228 & 158 & 158 & 181 & 22 \\
\hline Hugh White Creek & 57 & 3 & 117 & 59 & 97 & 48 & 16 & 57 & 40 & 53 \\
\hline Alta Creek & -126 & -142 & -141 & -136 & -7 & 21 & 18 & 19 & 19 & 8 \\
\hline Stonecrop Creek & 254 & 325 & 330 & 303 & 14 & 52 & 57 & 57 & 55 & 5 \\
\hline Greenbrier Creek & -354 & -503 & -482 & -446 & -18 & 133 & 108 & 112 & 118 & 11 \\
\hline
\end{tabular}

$\dagger K_{\mathrm{m}}$ and $U_{\max }$ values derived from two-point regressions. 

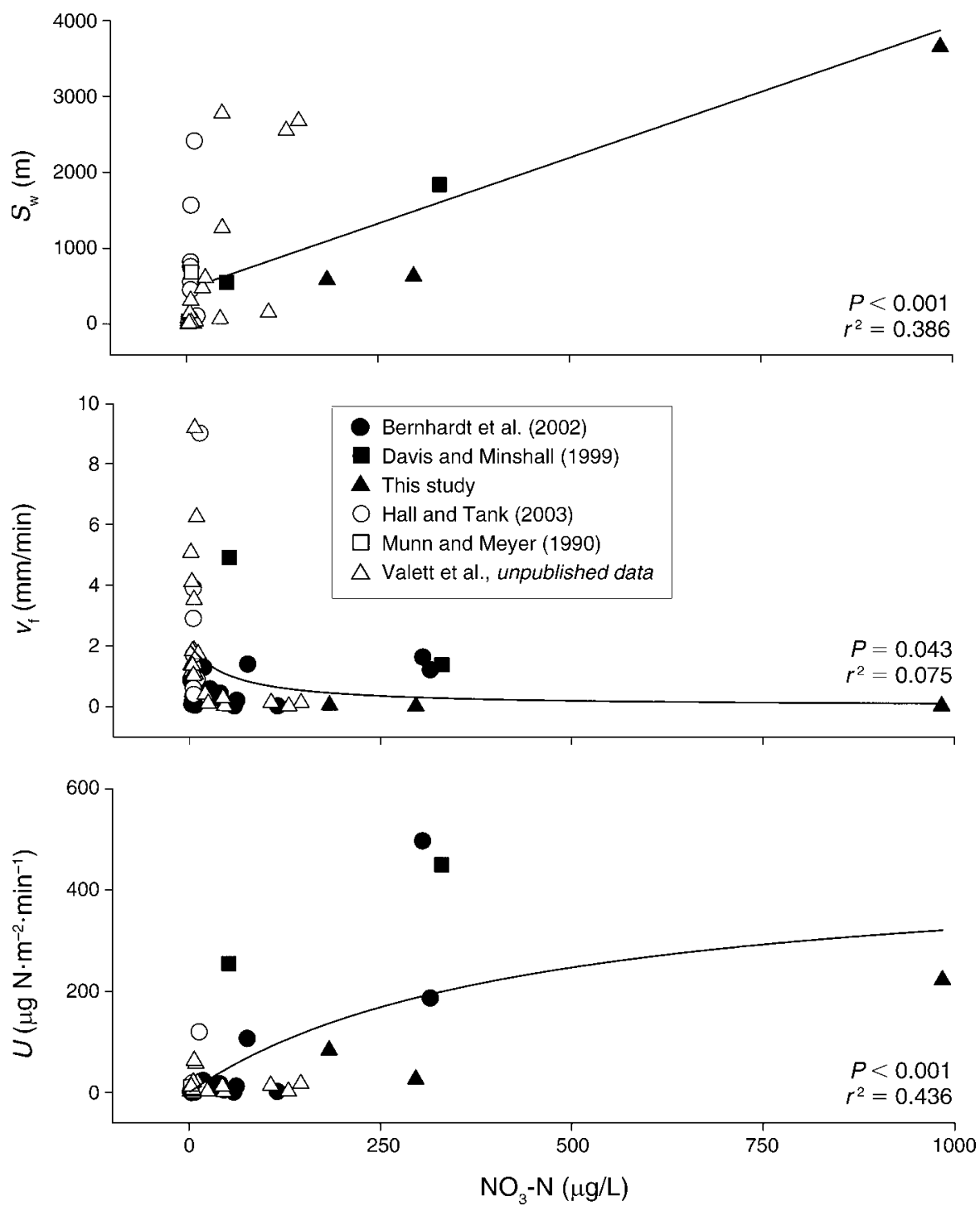

FIG. 4. Cross-study comparison of $\mathrm{NO}_{3}-\mathrm{N}$ spiraling across a N-concentration gradient. Regression results correspond to Eqs. 5,4 , and 1 for uptake length $\left(S_{\mathrm{w}}\right)$, uptake velocity $\left(v_{\mathrm{f}}\right)$, and uptake $(U)$, respectively. Data sources are given in the figure; note that for Hall and Tank (2003), sites with infinite uptake lengths were excluded.

These patterns were evident, though less robust statistically, in a cross-stream, cross-study comparison of $\mathrm{NO}_{3}-\mathrm{N}$ spiraling in streams throughout the coterminous United States that span a $\mathrm{N}$ gradient (Fig. 4). We observed statistically significant relationships between ambient $\mathrm{NO}_{3}-\mathrm{N}$ concentration and uptake length $\left(r^{2}=\right.$ $0.386, P<0.001)$, uptake velocity $\left(r^{2}=0.075, P=\right.$ $0.043)$, and uptake $\left(r^{2}=0.436, P<0.001\right)$, following Eqs. 5, 4, and 1, respectively.

\section{Discussion}

Biotic control of $N$ uptake: whole stream measures

The relationships between $S_{\mathrm{w}}, v_{\mathrm{f}}, U$, and $\mathrm{NO}_{3}-\mathrm{N}$ amendment corresponded to predicted patterns given M-M kinetics in four of six study streams. These results suggest that biological processes are responsible for $\mathrm{N}$ uptake, and that uptake can be modeled according to M-M kinetics, but that alternate models of nutrient uptake may be more applicable in high-N streams. In contrast, Dodds et al. (2002) reported continual increase in $\mathrm{N}$ uptake, despite very high amendment concentrations in prairie streams. They proposed that the apparent lack of biotic saturation might have been due to hydrodynamic limitation across solid-water boundaries (i.e., mass transport limitation). Diffusion (i.e., mass transfer) of nutrients may be limited by benthic biofilm thickness, and increasing water velocity has been shown to stimulate growth of biofilms (Horner et al. 1990, Battin 2000). If uptake is limited solely by mass transport, uptake should be a linear function of 


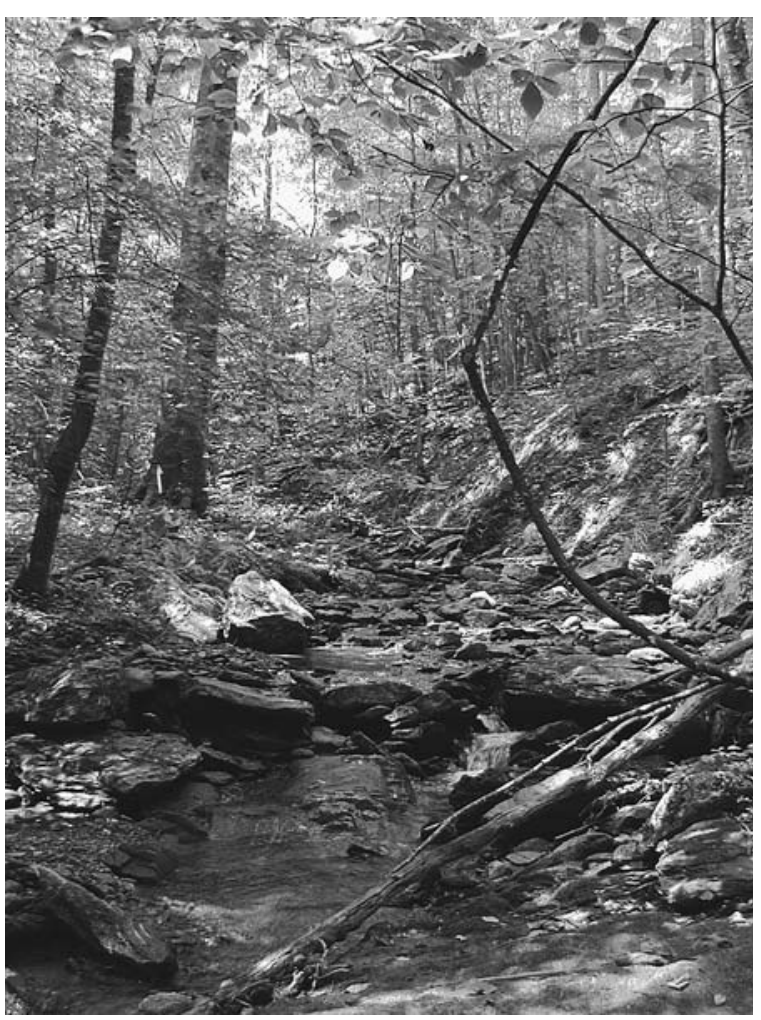

Plate 1. Alta Creek, Montgomery County, Virginia (USA). Site of ${ }^{15} \mathrm{~N}$ releases in August 2003. Photo credit: S. Earl.

concentration, and both $S_{\mathrm{w}}$ and $v_{\mathrm{f}}$ would remain constant (Dodds et al. 2002). Biomass of benthic biofilms was low in these streams (Earl 2004), making it likely that biotic processes (i.e., uptake kinetics) were more important than diffusion-limited uptake in our streams.

Whole-stream estimates of $K_{\mathrm{m}}(3-330 \mu \mathrm{g} / \mathrm{L}$, excluding Alta Creek and Greenbrier Creek) are generally within the range of those reported for other stream ecosystems and for freshwater algae. Whole-stream estimates of $K_{\mathrm{m}}$ ranged from $6 \mu \mathrm{g}$ to $32 \mu \mathrm{g} \mathrm{NH}_{4}-\mathrm{N} / \mathrm{L}$ in prairie and mountain streams (Payn et al. 2005). Reported $K_{\mathrm{m}}$ values for freshwater algae include $59 \mu \mathrm{g} \mathrm{NO}_{3}-\mathrm{N} / \mathrm{L}$ for a periphyton assemblage (Kim et al. 1990), 1.4-130 $\mu \mathrm{g} \mathrm{N} /$ $\mathrm{L}$ for diatoms (USEPA 1985), and 102- $213 \mu \mathrm{g} \mathrm{NO}-\mathrm{N} /$ $\mathrm{L}$ for filamentous green alga (Cladophora glomerata, Lohman and Priscu 1992). General agreement between our estimates of $K_{\mathrm{m}}$ and those reported in the literature for micro- and mesocosm studies (where the influence of mass transport and adsorption is negligible) further supports biotic regulation of uptake in our study streams.

\section{Saturation response types}

The study sites spanned a continuum from potentially $\mathrm{N}$-limited to $\mathrm{N}$-saturated streams. An increase in uptake $(U)$ with increasing $\mathrm{N}$ amendment at Sammy Creek,
Stonecrop Creek, and Hugh White Creek suggests that $\mathrm{N}$ uptake in these streams was not saturated. We observed evidence of Saturation Response Type (SRT) I at Hugh White Creek, and while the relationship between $U$ and $\mathrm{NO}_{3}-\mathrm{N}$ amendment at this site was best described by a linear model, visual inspection of the relationship suggested a slight nonlinear trend. This pattern may reflect a transition between SRTs I and II, or may result from the substantial range of $\mathrm{NO}_{3}-\mathrm{N}$ amendment concentration used to address saturation in this stream. Very low background DIN concentration at Hugh White Creek resulted in amendments that elevated $\mathrm{NO}_{3}-\mathrm{N} \sim 1$ - to 164-fold across the four releases while experimental enrichment varied from 1- to 58-fold at all other sites. Both experiments at Sammy Creek indicated that it was well below $\mathrm{N}$ saturation (SRT I). Although the relationship between $U$ and $\mathrm{NO}_{3}-\mathrm{N}$ amendment could not be resolved due to the limited number of data points, uptake increased dramatically (a higher proportion of ambient $U$ than in any other stream) despite a very high enrichment on both occasions. We observed evidence of SRT II at Stonecrop Creek, where $U$ increased with increasing $\mathrm{NO}_{3}-\mathrm{N}$ amendment, according to an asymptotic relationship, and was approaching $U_{\text {max }}$ at the highest amendment. Uptake did not increase significantly at Greenbrier Creek, corresponding to an SRT III and suggesting that uptake in this stream was saturated. Similarly, $U$ did not increase significantly with increasing $\mathrm{NO}_{3}-\mathrm{N}$ amendment at Alta Creek, suggesting that this system was also $\mathrm{N}$ saturated.

Based on our model, the relationship between $U$ and $\mathrm{NO}_{3}-\mathrm{N}$ amendment at both Alta Creek and Greenbrier Creek denotes $\mathrm{N}$ saturation. However, visual inspection of the relationships suggests that $U$ declined with increasing $\mathrm{NO}_{3}-\mathrm{N}$ concentration at both sites, a trend not consistent with the M-M model. While the linear increase in $S_{\mathrm{w}}$ and nonlinear decline in $v_{\mathrm{f}}$ associated with $\mathrm{NO}_{3}-\mathrm{N}$ augmentation at these sites correspond to predicted patterns given $\mathrm{M}-\mathrm{M}$ kinetics, the mathematical relationships resulted in similar nonsensical estimates of $K_{\mathrm{m}}$ and $U_{\max }$. Further, the significantly greater slope of the relationship between $S_{\mathrm{w}}$ and $\mathrm{NO}_{3}-\mathrm{N}$ amendment at both Alta Creek and Greenbrier Creek relative to all other sites suggests that these streams behaved differently than the other study streams with respect to $\mathrm{N}$ uptake.

These results suggest that alternate models of uptake of a given nutrient may be more applicable when streams are no longer limited by that nutrient (i.e., saturated). An increase in the availability of a nonlimiting nutrient should not alter uptake rates for that nutrient. Thus, the asymptotic relationship between $U$ and nutrient concentration described by the M-M model may be truncated and, instead, should be modeled as zero-order (i.e., constant rate and slope of zero) as nutrient concentration increases beyond saturation (Dugdale et al. 1981). Traditionally, M-M model assessment addresses how reaction rates are limited by 
enzymatic kinetics. In real ecosystems, uptake and processing of one element may be influenced by the availability of another (Fairchild et al. 1985), and we contend that the transition in $U$ from an asymptotic rise to a zero-order is illustrated by break points in other spiraling metrics as well. Specifically, the slope of the linear relationship between uptake length and concentration should be markedly steeper at concentrations in excess of saturation. At the same time, the transition to saturation should correspond to a greater rate of decline in nutrient uptake efficiency. Deviation of $U$ from expected asymptotic increase, coupled with the significantly steeper slopes of the relationship between $S_{\mathrm{w}}$ and $\mathrm{NO}_{3}-\mathrm{N}$ amendment we observed at Alta Creek and Greenbrier Creek, correspond to expected patterns for systems exposed to $\mathrm{N}$ concentration in excess of saturation (i.e., model truncation). These observations suggest abrupt and nonlinear changes in $\mathrm{N}$ removal during stream transport with consequences for receiving waters. Such dramatic changes in $\mathrm{N}$ dynamics are central to the $\mathrm{N}$-saturation hypothesis proposed for other ecosystems (Aber et al. 1998, Perakis et al. 2005).

The proximity of streams to $\mathrm{N}$ saturation, as indicated by their respective SRT was generally correlated to stream water nutrient concentration. Streams designated SRT I were low-N systems (Sammy Creek and Hugh White Creek). Our findings that low-N streams are not saturated concur with studies that reported $\mathrm{N}$ limitation at similar $\mathrm{N}$ concentrations. Benthic algae were $\mathrm{N}$ limited when concentrations were below $55 \mu \mathrm{g} \mathrm{NO}_{3}-\mathrm{N} / \mathrm{L}$ in a desert stream (Grimm and Fisher 1986) and below $100 \mu \mathrm{g} \mathrm{NO}_{3}-\mathrm{N} / \mathrm{L}$ in an Ozark (USA) stream (Lohman et al. 1991). At the opposite end of the spectrum, streams designated SRT III (Alta Creek and Greenbrier Creek) had high $\mathrm{N}$ concentration. Our analysis indicated that Stonecrop Creek was approaching $\mathrm{N}$ saturation (i.e., characteristic of SRT II) but that the stream was not saturated, despite comparatively higher $\mathrm{N}$ concentration. Ultimately, nutrient saturation occurs when the availability of a nutrient increases to a point at which another factor critical to growth becomes limiting. In headwater stream ecosystems, nitrogen (Grimm and Fisher 1986), phosphorus (Hart and Robinson 1990), some combination of $\mathrm{N}$ and P (Winterbourn 1990), or other environmental factors (e.g., light; Lowe et al. 1986) often limit primary and secondary production. Lack of N saturation at Stonecrop Creek may reflect the high concentration of SRP in that stream, which resulted in a stream-water molar N:P ratio of 16 . In a study of benthic algae, Shanz and Juon (1983) suggested that $\mathrm{N}$ was limiting at $\mathrm{N}: \mathrm{P}$ ratios $<10, \mathrm{P}$ was limiting at $\mathrm{N}: \mathrm{P}$ ratios $>20$, and the limiting nutrient was ambiguous at N:P ratios between 10 and 20. Nutrient ratios are useful for identifying limiting nutrients when concentrations are near growth-limiting concentrations (Borchardt 1996). Our analysis of N saturation in these study streams is consistent with the thresholds identified by Shanz and Juon (1983) and suggest that Stonecrop
Creek may not be $\mathrm{N}$ or $\mathrm{P}$ limited, whereas high $\mathrm{N}$ concentrations in Alta Creek and Greenbrier Creek may result in $\mathrm{P}$ limitation.

\section{Stream response to chronic $N$ loading}

Nutrient uptake and biomass accrual are coupled only under steady-state conditions (Borchardt 1996), thus the uptake kinetics calculated from our short-term $\mathrm{N}$ amendments do not necessarily reflect kinetics that might be associated with long-term $\mathrm{N}$ loading within a given stream. However, $\mathrm{N}$ uptake and uptake efficiency are functions of biotic demand and nutrient concentration in all ecosystems. As such, spiraling metrics should respond in a characteristic fashion based on chronic $\mathrm{N}$ concentration. Predicted spiraling response across a gradient of $\mathrm{N}$ concentration translates into phases of $\mathrm{N}$ saturation analogous to the saturation response types (SRTs) described previously. We contend that, for streams experiencing low chronic levels of inorganic $\mathrm{N}$, a restricted portion of the domain exists where the extant biota is able to use $\mathrm{N}$ subsidies in their entirety (Davis and Minshall 1999). Thus, phase I of $\mathrm{N}$ saturation in streams is described by short uptake lengths $\left(S_{\mathrm{w}}\right)$, high uptake efficiency $\left(v_{\mathrm{f}}\right)$, but relatively low uptake due to limited $\mathrm{N}$ availability. The $\mathrm{N}$ concentrations characteristic of phase I will depend on ambient standing stocks and diversity of stream biota responsible for primary uptake from the water column. Nevertheless, it appears that phase I is restricted to very low $\mathrm{N}$ concentrations. In Hugh White Creek, for example, despite a linear increase in uptake $(U)$ as $\mathrm{N}$ increased from 3 to $>500 \mu \mathrm{g} / \mathrm{L}$, we observed an increase in uptake length $\left(S_{\mathrm{w}}\right)$ and nonlinear decline in uptake velocity $\left(v_{\mathrm{f}}\right)$. While the stream was categorized as SRT I based on change in $U$, other metrics suggest that SRT II may be more appropriate for this range of $\mathrm{N}$ exposure. These responses suggest that streams may pass from phase I to phase II as ambient $\mathrm{N}$ increases only a very small amount. Further, this case illustrates how results from our assays of $\mathrm{N}$ saturation are sensitive to the range of $\mathrm{N}$ additions and their potential to alter patterns of ecosystem response. Accordingly, $\mathrm{N}$ saturation response curves must be interpreted in the context of the proposed extent of $\mathrm{N}$ enrichment. Uptake should be comparatively greater, uptake lengths longer, and uptake efficiencies lower (in accordance with the M-M model) in moderately enriched systems that correspond to phase II of $\mathrm{N}$ saturation. High-N systems (e.g., Greenbrier Creek and Alta Creek) indicative of the third phase of $\mathrm{N}$ saturation are characterized by relatively high uptake but markedly reduced uptake efficiency. At the same time, uptake lengths will be considerably longer in phase III as $\mathrm{N}$ atoms are transported increasingly longer distances before interaction with biotic sinks. Uptake did not change significantly, but $S_{\mathrm{w}}$ increased and $v_{\mathrm{f}}$ decreased dramatically at Greenbrier Creek, for 
example, despite comparatively minute $\mathrm{N}$ additions relative to ambient concentration.

Spiraling metrics under ambient $\mathrm{N}$ concentration in our study stream corresponded generally to predicted phases of $\mathrm{N}$ saturation. These patterns were also evident, though less robust, in a cross-study comparison of $\mathrm{NO}_{3}-\mathrm{N}$ spiraling in disparate streams spanning a gradient of $\mathrm{N}$ concentration. While biotic processes are ultimately responsible for $\mathrm{N}$ cycling within streams (Hall and Tank 2003, Simon et al. 2005), these processes are influenced by a multitude of in-stream environmental variables, contributing to the considerable but expected variability within these relationships.

The high $\mathrm{NO}_{3}-\mathrm{N}$ uptake efficiency in our low-N streams contributes to a growing body of evidence that documents the importance of streams as N-retention features on the landscape (e.g., Alexander et al 2000, Peterson et al. 2001, Bernhardt et al. 2003). However, our data show that the nature of $\mathrm{N}$ retention may change abruptly in response to $\mathrm{N}$ inputs. Regardless of uptake response, uptake efficiency declined nonlinearly with increasing experimental $\mathrm{N}$ amendment to streams. We also observed a pattern of decreasing uptake efficiency with higher background stream water $\mathrm{N}$ concentration (Fig. 4). These patterns are expected given $\mathrm{M}-\mathrm{M}$ kinetics but also indicate that even unsaturated streams are less efficient retainers of $\mathrm{N}$ in the face of increased $\mathrm{N}$ loading. Annual rates of $\mathrm{N}$ loading into freshwater ecosystems has increased 6- to 50 -fold since pre-industrial times, resulting in global fertilization in continental, estuarine, and near-coastal marine environments (Carpenter et al. 1998). Our analysis suggests that the capacity of streams to mitigate downstream fluxes of $\mathrm{N}$ is limited, potential retention or removal efficiency declines dramatically with even moderate inputs of $\mathrm{N}$, and that streams may act to propagate $\mathrm{N}$ saturation down-gradient rapidly if $\mathrm{N}$ additions are not actively curtailed.

\section{ACKNOWLEDGMENTS}

We thank members of the Virginia Tech Stream Team for assistance in the field and laboratory. E. F. Benfield, C. G. Peterson, and T. A. Dillaha provided valuable comments on earlier versions of this manuscript. We also appreciate the help of two anonymous reviewers whose comments improved the manuscript. Funding for this project was provided by grants from the National Science Foundation (DEB 0206443), the Virginia Academy of Science, and Virginia Polytechnic Institute and State University.

\section{Literature Cited}

Aber, J., W. McDowell, K. Nadelhoffer, A. Magill, G. Bernston, M. Kamakea, S. McNulty, W. Currie, L. Rustad, and I. Fernandez. 1998. Nitrogen saturation in temperate forest ecosystems. BioScience 48:921-934.

Aber, J. D., K. J. Nadelhoffer, P. Steudler, and J. M. Melillo. 1989. Nitrogen saturation in northern forest ecosystems. BioScience 39:378-386.

Alexander, R. B., R. A. Smith, and G. E. Schwarz. 2000. Effect of stream channel size on the delivery of nitrogen to the Gulf of Mexico. Nature 503:758-761.
APHA (American Public Health Association). 1998. Standard methods for the examination of water and wastewater. 20th edition. APHA, New York, New York, USA.

Battin, T. J. 2000. Hydrodynamics is a major determinant of streambed biofilm activity: from the sediment to the reach scale. Limnology and Oceanography 45:1308-1319.

Bencala, K. E., D. M. McKnight, and G. W. Zellweger. 1990. Characterization of transport in an acidic metal-rich mountain stream based on a lithium tracer injection and simulations of transient storage. Water Resources Research 26:989-1000

Bencala, K. E., and R. A. Walters. 1983. Simulation of solute transport in a mountain pool-and-riffle stream: a transient storage model. Water Resources Research 19:718-724.

Bernhardt, E. S., R. O. Hall, Jr., and G. E. Likens. 2002. Whole-system estimates of nitrification and nitrate uptake in streams of the Hubbard Brook Experimental Forest. Ecosystems 5:419-430.

Bernhardt, E. S., G. E. Likens, D. C. Buso, and C. T. Driscoll. 2003. In-stream uptake dampens effects of major forest disturbance on watershed nitrogen export. Proceedings of the National Academy of Science (USA) 100:10304-10308.

Borchardt, M. A. 1996. Nutrients. Pages 183-227 in R. J. Stevenson, M. L. Bothwell, and R. L. Lowe, editors. Algal ecology. Academic Press, San Diego, California, USA.

Carpenter, S. R., N. F. Caraco, D. L. Correll, R. W. Howarth, A. N. Sharpley, and V. H. Smith. 1998. Nonpoint pollution of surface waters with phosphorus and nitrogen. Ecological Applications 8:559-568.

Davis, J. C., and G. W. Minshall. 1999. Nitrogen and phosphorus uptake in two Idaho (USA) headwater wilderness streams. Oecologia 119:247-255.

Dodds, W. K., et al. 2002. N uptake as a function of concentration in streams. Journal of the North American Benthological Society 21:206-220.

Dugdale, R. C., B. H. Jones, Jr., and J. J. MacIssac. 1981. Adaptation of nutrient assimilation. Canadian Bulletin of Fisheries and Aquatic Sciences 210:234-350.

Earl, S. R. 2004. Nitrogen spiraling in stream ecosystems spanning a gradient of chronic nitrogen loading. Dissertation. Virginia Polytechnic Institute and State University, Blacksburg, Virginia, USA.

Fairchild, G. W., R. L. Lowe, and W. B. Richardson. 1985. Algal periphyton growth on nutrient-diffusing substrates: an in situ bioassay. Ecology 66:465-472.

Grimm, N. B., and S. G. Fisher. 1986. Nitrogen limitation in a Sonoran Desert stream. Journal of the North American Benthological Society 5:2-15.

Hagen, E. M., J. R. Webster, and E. F. Benfield. 2006. Are leaf breakdown rates a useful measure of stream integrity along an agricultural land use gradient? Journal of the North American Benthological Society 25:330-343.

Hall, R. O. 2003. A stream's role in watershed nutrient export. Proceedings of the National Academy of Science (USA) 100: 10137-10138.

Hall, R. O., and J. L. Tank. 2003. Ecosystem metabolism controls nitrogen uptake in streams in Grand Teton National Park, Wyoming. Limnology and Oceanography 48:11201128.

Hart, D. D., and C. T. Robinson. 1990. Resource limitation in a stream community: phosphorus enrichment effects on periphyton and grazers. Ecology 71:1494-1502.

Horner, R. R., E. B. Welch, M. R. Seeley, and J. M. Jacoby. 1990. Responses of periphyton to changes in current velocity, suspended sediment and phosphorus concentration. Freshwater Biology 24:215-232.

Kim, B. P., A. P. Jackman, and F. J. Triska. 1990. Modeling transient storage and nitrate uptake kinetics in a flume containing a natural periphyton community. Water Resources Research 26:505-515. 
Lohman, K., J. R. Jones, and C. Baysinger-Daniel. 1991. Experimental evidence for nitrogen limitation in a northern Ozark stream. Journal of the North American Benthological Society 10:14-23.

Lohman, K., and J. C. Priscu. 1992. Physiological indicators of nutrient deficiency in Cladophora (Chlorophyta) in the Clark Fork of the Colombia River, Montana. Journal of Phycology 28:443-448.

Lowe, R. L., S. W. Golladay, and J. R. Webster. 1986. Periphyton response to nutrient manipulation in streams draining clearcut and forested watersheds. Journal of the North American Benthological Society 5:221-229.

McTammany, M. E. 2004. Recovery of southern Appalachian streams from historical agriculture. Dissertation. Virginia Polytechnic Institute and State University, Blacksburg, Virginia, USA.

Mulholland, P. J., J. L. Tank, D. M. Sanzone, W. M. Wollheim, B. J. Peterson, J. R. Webster, and J. L. Meyer. 2000. Nitrogen cycling in a forest stream determined by a ${ }^{15} \mathrm{~N}$ tracer addition. Ecological Monographs 70:471-493.

Munn, N. L., and J. L. Meyer. 1990. Habitat-specific solute retention in two small streams: an intersite comparison. Ecology 71:2069-2082.

Murphy, J., and J. P. Riley. 1962. Determination of phosphate in natural waters. Analytica Chimica Acta 27:31-36.

Newbold, J. D., J. W. Elwood, R. V. O'Neill, and W. Van Winkle. 1981. Measuring nutrient spiraling in streams. Canadian Journal of Fisheries and Aquatic Sciences 38: 860-863.

Payn, R. A., J. R. Webster, P. J. Mulholland, H. M. Valett, and W. K. Dodds. 2005. Estimation of stream nutrient uptake from nutrient addition experiments. Limnology and Oceanography: Methods 3:174-182.

Perakis, S. S., J. E. Compton, and L. O. Hedin. 2005. Nitrogen retention across a gradient of ${ }^{15} \mathrm{~N}$ additions to an unpolluted temperate forest soil in Chile. Ecology 86:96-105.

Peterson, B. J., et al. 2001. Control of nitrogen export from watersheds by headwater streams. Science 292:86-90.

Shanz, F., and J. Juon. 1983. Two different methods of evaluating nutrient limitations of periphyton bioassays using water from the River Rhine and eight of its tributaries. Hydrobiologia 102:187-195.

Sigman, D. M., M. A. Altabet, R. Michener, D. C. McCorkle, B. Fry, and R. M. Holmes. 1997. Natural abundance level measurement of the nitrogen isotopic composition of oceanic nitrate: an adaptation of the ammonia diffusion method. Marine Chemistry 57:227-242.

Simon, K. S., C. R. Townsend, B. J. F. Biggs, and W. B. Bowden. 2005. Temporal variation of $\mathrm{N}$ and $\mathrm{P}$ uptake in 2 New Zealand streams. Journal of the North American Benthological Society 24:1-18.

Solorzano, L. 1969. Determination of ammonia in natural waters by the phenolhypochlorite method. Limnology and Oceanography 14:779-801.

Stream Solute Workshop. 1990. Concepts and methods for assessing solute dynamics in stream ecosystems. Journal of the North American Benthological Society 9:95-119.

U.S. Environmental Protection Agency (USEPA). 1985. Rates, constants, and kinetics: formulations in surface water quality modeling. USEPA/600/3-85/040. Second edition. Washington, D.C., USA.

U.S. Environmental Protection Agency (USEPA). 1997a. Method 349.0. Determination of ammonia in estuarine and coastal waters by gas segmented continuous flow colorimetric analysis. In J. Z. Zhang, P. B. Ortner, C. J. Fischer, and L. D. Moore. Methods for the determination of chemical substances in marine and estuarine environmental matrices. Second edition. USEPA/600/R-97/072. National Exposure Research Laboratory, Cincinnati, Ohio, USA.

U.S. Environmental Protection Agency (USEPA). $1997 b$. Method 365.5. Determination of orthophosphate in estuarine and coastal waters by automated colorimetric analysis. In C. F. Zimmerman and C. W. Keefe. Methods for the determination of chemical substances in marine and estuarine environmental matrices. Second edition. USEPA/600/R-97/ 072. National Exposure Research Laboratory, Cincinnati, Ohio, USA.

Webster, J. R., and B. C. Patten. 1979. Effects of watershed perturbation on stream potassium and calcium dynamics. Ecological Monographs 49:51-72.

Winterbourn, M. J. 1990. Interactions among nutrients, algae and invertebrates in a New Zealand mountain stream. Freshwater Biology 23:463-474.

Wood, E. D., F. A. J. Armstrong, and F. A. Richards. 1967. Determination of nitrate in seawater by cadmium-copper reduction to nitrite. Journal of the Marine Biological Association of the United Kingdom 47:23-31. 